\title{
Fast and Efficient Removal of Iron from Industrial Wastewater Using Electrochemical Deposition
}

\author{
Rasha A. Hefny ${ }^{1}$, Omar E. Abdel-Salam ${ }^{2}$, Ali M. Basstawesy ${ }^{1}$, \\ Mohamed H. Mahmoud ${ }^{2}$, and Nasser A. M. Barakat ${ }^{1, *}$ \\ ${ }^{1}$ Chemical Engineering Department, Faculty of Engineering, Minia University, Egypt \\ ${ }^{2}$ Chemical Engineering Department, Faculty of Engineering, Cairo University, Egypt \\ *E-mail: nasbarakat@minia.edu.eg
}

doi: $10.20964 / 2019.09 .56$

Received: 18 February 2019 / Accepted: 26 June 2019 / Published: 5 August 2019

\begin{abstract}
Among the proposed methodologies for heavy metal removal from industrial wastewaters, electrochemical treatment has drawn attention due to its simplicity and high performance. In this study, experiments were carried out using a bench-scale electrochemical cell incorporating a flow-by porous graphite electrode for iron removal. The influence of the initial iron concentration, feed flow rate, and current density on the removal efficiency and current efficiency were studied. The maximum removal efficiency (99.7\%) was obtained after $10 \mathrm{~min}$ of operation at a flow rate of $0.278 \mathrm{ml} / \mathrm{s}$, a current density of $0.98 \mathrm{~mA} / \mathrm{cm}^{2}$ and a $\mathrm{pH}$ of 4 , and a maximum current efficiency of $95.5 \%$ was obtained at a flow rate of $0.833 \mathrm{ml} / \mathrm{s}$ for an initial iron concentration of $200 \mathrm{ppm}$.
\end{abstract}

Keywords: iron removal; electrochemical cell; flow-by electrode

\section{$\underline{\text { FULL TEXT }}$}

(C) 2019 The Authors. Published by ESG (www.electrochemsci.org). This article is an open access article distributed under the terms and conditions of the Creative Commons Attribution license (http://creativecommons.org/licenses/by/4.0/). 